\begin{tabular}{|l|l|l||}
\hline \multicolumn{2}{|c|}{ PublisherInfo } \\
\hline \hline PublisherName & $:$ & BioMed Central \\
\hline \hline PublisherLocation & $:$ & London \\
\hline \hline PublisherImprintName & $:$ & BioMed Central \\
\hline \hline
\end{tabular}

\title{
Brain boost for the UK
}

\begin{tabular}{|l|l|l||}
\hline \multicolumn{2}{|c|}{ ArticleInfo } \\
\hline \hline ArticleID & $:$ & 4912 \\
\hline \hline ArticleDOI & $:$ & 10.1186 /gb-spotlight-20040210-01 \\
\hline \hline ArticleCitationID & $:$ & spotlight-20040210-01 \\
\hline \hline ArticleSequenceNumber & $:$ & 264 \\
\hline \hline ArticleCategory & $:$ & Research news \\
\hline ArticleFirstPage & $:$ & 1 \\
\hline \hline ArticleLastPage & $:$ & 3 \\
\hline \hline & & RegistrationDate : 2004-2-10 \\
\hline ArticleHistory & $:$ & OnlineDate \\
\hline \hline ArticleCopyright & $:$ & BioMed Central Ltd2004-10 \\
\hline \hline ArticleGrants & $:$ & \\
\hline \hline ArticleContext & $:$ & 130594411 \\
\hline \hline
\end{tabular}




\section{Stephen Pincock}

Email: Stephen@thescientisteurope.com

The winners of $£ 5$ million worth of grants for basic and clinical neuroscience were announced by Britain's Medical Research Council (MRC) as part of a push to strengthen the UK's position in the field.

The 29 grants cover a wide variety of scientific approaches to address disorders such as depression, Alzheimer disease, Parkinson disease, Huntington disease, schizophrenia, and bipolar disorder, the MRC said.

Brain science is among the top areas of medical research in Britain, said Nancy Rothwell, professor of neuroscience at the University of Manchester. "It's generally world leading with a lot of very, very strong work going on," she told us. "Although, like every discipline, it is fighting for limited funds."

The awards are made as a result of the first round of the MRC's call for proposals for brain science research in the middle of last year. The call was arranged into two themes: 'Trial Platforms,' moving toward clinical trials, and 'Pathfinders,' for building knowledge and capacity for future research.

They include basic research into genetics, biological markers and mechanisms of disease, the use of imaging techniques or better exploitation of existing technology, and the creation of new packages of care for mental health and future development of clinical trials.

A total of $£ 2.23$ million was awarded for 11 Trial Platforms and $£ 2.82$ million for 18 Pathfinder grants.

Rothwell, who led the Trial Platforms panel, said the winning projects tended toward higher-risk research and younger investigators, including some at the very beginning of their careers. "We were quite surprised by the number and quality of applications," she said. Four projects were for international collaborations.

Neuroscience has been at the top of the British news agenda over recent weeks due to the decision by Cambridge University to cancel a planned facility devoted to neurological studies in primates.

Cambridge cited rising costs as the basis for the decision, but it has been widely seen as a response to the violent tactics of a small number of animal rights activists who have become active in Britain in recent years. Huntingdon Life Sciences, which is based near where the new center would have been built, has been a particular target.

The current round of funding includes one project involving primates. "We certainly didn't exclude it [primate research]," Rothwell said.

David Armstrong, who chaired the Trial Platform panel, said in a statement that two thirds of all the grants awarded were for clinical research. "Some of these platforms create potential for large-scale trials in the future, but many could have an immediate impact on care and the ways in which it is provided for patients and their families," he added. 
The applications were also more cost-effective than expected, said Colin Blakemore, chief executive of the MRC. "We've been able to support a third more projects than we anticipated at the outset."

The second phase of the MRC brain sciences initiative will be a new call for proposals in summer 2004. Details are yet to be confirmed.

\section{References}

1. Medical Research Council Brain Sciences Call 2003 - Successful Applicants, [http://www.mrc.ac.uk/ funding-bscall-successful.htm]

2. Nancy Rothwell, [http://www.mrc.ac.uk/index/about/about-organisation/about-bodies_and_members/ about-mrc_council/about-council_members_profiles.htm\#anchor-rothwell]

3. Hunter P: UK animal lab scrapped The Scientist, January 30, 2004., [http://www.the-scientist.com/ news/20040130/03/]

4. Brain Science, Medical Research Council, [http://www.mrc.ac.uk/index/public-interest/publictopical_issues/public-brain_science.htm] 